Article

\title{
The Potential of Switchgrass and Miscanthus to Enhance Soil Organic Carbon Sequestration-Predicted by DayCent Model
}

\author{
Marek Jarecki ${ }^{1}$, Kumudinie Kariyapperuma ${ }^{1,+}{ }^{\dagger}$ Bill Deen ${ }^{2}$, Jordan Graham ${ }^{3}$, \\ Amir Behzad Bazrgar ${ }^{1}$ (D), Sowthini Vijayakumar ${ }^{1}$ (D, Mahendra Thimmanagari ${ }^{4}$, \\ Andrew Gordon ${ }^{1}$, Paul Voroney ${ }^{1}$ and Naresh Thevathasan ${ }^{1, *(D)}$ \\ 1 School of Environmental Sciences, University of Guelph, 50 Stone Road E, Guelph, ON N1G 2W1, Canada; \\ jareckim@uoguelph.ca (M.J.); kkumudin@alumni.uoguelph.ca (K.K.); abazrgar@uoguelph.ca (A.B.B.); \\ sowthini@uoguelph.ca (S.V.); agordon@uoguelph.ca (A.G.); pvoroney@uoguelph.ca (P.V.) \\ 2 Department of Plant Agriculture, University of Guelph, 50 Stone Road E, Guelph, ON N1G 2W1, Canada; \\ bdeen@uoguelph.ca \\ 3 Ontario Soil and Crop Improvement Association, 1 Stone Road W, Guelph, ON N1G 4Y2, Canada; \\ Jgraham@ontariosoilcrop.org \\ 4 Ontario Ministry of Agriculture, Food and Rural Affairs, 1 Stone Road W, Guelph, ON N1G 4Y2, Canada; \\ mahendra.thimmanagari@ontario.ca \\ * Correspondence: nthevath@uoguelph.ca; Tel.: +1-519-824-4120 (ext. 52565) \\ + Office of Research Services, Wilfrid Laurier University, 75 University Avenue West, \\ Waterloo Ontario, N2L 3C5, Canada.
}

Received: 25 September 2020; Accepted: 7 December 2020; Published: 10 December 2020

\begin{abstract}
Warm season perennial C4 grasses (WSGs), switchgrass (Panicum virgatum L.) and miscanthus species (Miscanthus spp.), have been reported to positively influence short-term (15-20 years) soil organic carbon (SOC). In this study, the DayCent model was used to predict changes in long-term SOC stocks under WSGs for moderate (Representative Concentration Pathway (RCP) 4.5) and high (RCP 8.5) warming climate change scenarios in southern Ontario, Canada, and to determine how long the enhanced SOC stock will last when WSGs are converted back to annual crop rotation. The model predicted that a consistent corn-corn-soybean-winter wheat (CCSW) rotation prevented SOC from depletion over the 21st century. Under WSGs, the model predicted high rates of SOC sequestration during the first 20-30 years which then tended to stabilize after 50-60 years. However, the rate of SOC sequestration over 90 years for RCP 4.5 was 0.26 and $0.94 \mathrm{MgC} \mathrm{ha}^{-1} \mathrm{yr}^{-1}$ for switchgrass and miscanthus, respectively. If 40-year stands of WSGs are converted back to CCSW, the model predicted SOC decline to the previous level in 40-50 years. DayCent predicted that under RCP 8.5 scenario in the second half of the 21st century and in the future, there will be a reduction in SOC stocks, especially under miscanthus stands.
\end{abstract}

Keywords: warm season C4 grasses; herbaceous biomass crops; climate scenarios

\section{Introduction}

To effectively mitigate climate change by the year 2100, the entire world needs to completely abandon the use of fossil fuels [1]. Bioenergy and biofuels are recommended as a major source of future energy to replace energy currently generated from fossil fuels [1]. Biomass can be used for biofuel production, or for heating and generation of electricity [2]. There has been a growing interest in using C4 perennial grasses as biomass feedstocks. Switchgrass (Panicum virgatum L.) and miscanthus species (Miscanthus spp.), often referred to as warm season grasses (WSGs), are examples of C4 perennial 
grasses grown in Canada [2]. WSG biomass can also be used as livestock bedding, as an ingredient of mushroom compost [3] or as a horticultural mulch [4]. Marsal et al. [5], Deen [6] and Bazrgar et al. [7] proposed that WSGs are the most suitable biomass crops to be grown in southern Ontario, especially on marginal lands, due to their high yields and low nutrient requirements. Additionally, they have a broad range in climatic tolerance and provide additional environmental benefits. WSGs are cultivated similarly to common Ontario hay and forage crops, thus do not require additional specialized farm equipment [6].

McCalmont et al. [8] have described the beneficial impact of WSGs on soil properties. These benefits are due to their perennial nature, high productivity and extensive root system, which reduce erosion and non-point source of water pollution. Several studies have shown that WSGs promote soil organic carbon (SOC) sequestration [7,9-11]. In Ontario, soil organic carbon stocks under WSGs were higher in comparison to SOC stocks in agricultural fields [12]. Extensive meta-analysis by Agostini et al., [13] presented changes to gross C inputs and SOC stocks by WSGs with annual net SOC storage of 1.14 to $1.88 \mathrm{Mg} \mathrm{C} \mathrm{ha}^{-1} \mathrm{yr}^{-1}$, significantly surpassing the minimum mitigation requirement of $0.25 \mathrm{Mg} \mathrm{C} \mathrm{ha}^{-1} \mathrm{yr}^{-1}$ [14]. However, long-term time series field data are needed to verify SOC enrichment [13].

Since long-term time series measurements of SOC change due to biomass cropping are scarce due to their inherent high spatial variability and to the high cost associated with field measurements, properly validated biogeochemical models can be used to predict such changes [15-17]. Biogeochemical models have been widely used for assessing interactions between climate, soils, and crop management practices on environmental outcomes including SOC storage [18]. Site-specific meteorological data combined with historical crop management practices, soil characteristics and auxiliary data can help to facilitate model calibration [17]. DayCent is an ecosystem process-based model and when properly validated by field observations is a powerful tool to investigate the effects of management practices on GHG emissions or on SOC changes in different ecosystems, soil types, and climates [19].

The DayCent model simulates soil and vegetation processes that control SOC dynamics and greenhouse gas emissions $[20,21]$ and studies have shown predictions of trends under different cropping systems in varied environmental conditions [22]. Miscanthus biomass production has been simulated in the DayCent model using plant growth parameters from Europe and Illinois [23]. Recent studies have presented extended evaluations of SOC changes over the 21st century by using varied Representative Concentration Pathway (RCP) scenarios [24,25]. IPCC proposed four RCP scenarios based on radiative forcing levels of 2.6, 4.5, 6.0, and $8.5 \mathrm{~W} \mathrm{~m}^{-2}$ by the end of the 21st century [1,26]. The moderate warming RCP 4.5 and high warming RCP 8.5 scenarios [24,25] are typically used for predictions of SOC changes.

The objectives of the study were: (i) to evaluate the ability of the DayCent model to simulate long-term SOC dynamics (over the 21st century) in switchgrass, miscanthus and conventional cropping systems (corn-corn-soybean-winter wheat (CCSW)) in Southern Ontario, Canada, (ii) to predict changes in SOC stocks under moderate and high warming climate change scenarios, and (iii) to determine how long enhanced SOC stocks will remain when WSG production systems are returned to annual cropping.

\section{Materials and Methods}

\subsection{Site Description}

The calibration data for DayCent simulation were obtained from field experiments conducted in Elora, Ontario, Canada $\left(43^{\circ} 4^{\prime} \mathrm{N}, 80^{\circ} 2^{\prime} \mathrm{W}\right)$. The soil at the field site has been mapped as a well-drained Woolwich silt loam and, according to the Canadian System of Soil Classification (CSSC), was described as a Gray Brown Luvisol [27], and according to World Reference Base (WRB) as an Albic Luvisol [28].

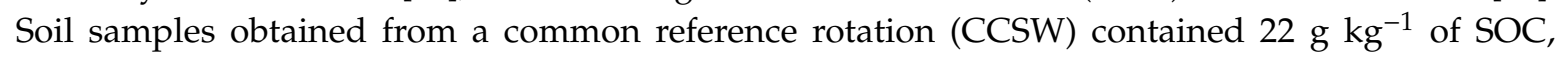
as determined by Leco combustion of 8 replicates taken in 2000 and 2015. During 1981 to 2015 , 
the average annual precipitation was $1009 \mathrm{~mm}$, with precipitation and temperature from May to September averaged $426 \mathrm{~mm}$ and 1008 growing degree days, respectively. Maximum and minimum temperatures were 11.4 and $1.8^{\circ} \mathrm{C}$, respectively.

\subsection{Crop Management}

From the long-term experiment (1981-2015) conducted at the same research station (Elora, ON, Canada), the crop rotation corn-corn (Zea mays L.) -soybean [Glycine max (L.) Merr.] -winter wheat (Triticum aestivum L.) (CCSW) data ertr selected as an agricultural reference. CCSW was managed with conventional tillage, which consisted of fall moldboard plowing and disking in spring prior to planting annual crops. Nitrogen fertilizer was applied annually as starter at planting $\left(11 \mathrm{~kg} \mathrm{~N} \mathrm{ha}^{-1}\right)$ and as a side-dress $\left(146 \mathrm{~kg} \mathrm{~N} \mathrm{ha}^{-1}\right)$ at corn sixth-leaf stage and for winter wheat as a spring application $\left(100 \mathrm{~kg} \mathrm{~N} \mathrm{ha}^{-1}\right)$. Switchgrass and Miscanthus were grown in 10-year stand rotations. Nitrogen fertilizer was applied in spring at a rate of $80 \mathrm{~kg} \mathrm{~N} \mathrm{ha}^{-1}$ for both grasses.

\subsection{DayCent Description and Input Parameters}

DayCent is biogeochemical model which has been used to simulate the impact of grassland and agricultural management practices on soil $\mathrm{C}$, trace gas fluxes $\left(\mathrm{CH}_{4}, \mathrm{NO}_{\mathrm{x}}\right.$, and $\left.\mathrm{N}_{2} \mathrm{O}\right)$, and $\mathrm{NO}_{3}$ leaching. DayCent simulates and describes the detailed processes of soil organic matter decomposition and external organic matter additions [20,29-31]. DayCent has been calibrated to accurately simulate biomass yields for a variety of crops, including corn and switchgrass, that are managed for biofuel feedstocks [32,33].

The DayCent model input parameters include long-term daily temperature and precipitation (obtained from Environment Canada [34]), soil properties including bulk density $\left(1.3 \mathrm{~g} \mathrm{~cm}^{-3}\right)$, water field capacity (31 vol\%), fraction of clay and sand (17 and 27\%, respectively), SOC content $\left(22 \mathrm{~g} \mathrm{~kg}^{-1}\right)$, saturated hydraulic conductivity $\left(15 \mathrm{~mm} \mathrm{~h}^{-1}\right)$ and $\mathrm{pH}$ of 7.3 . When soil hydraulic parameters such as field capacity and wilting point were not available for a site, the Saxton soil water characteristic calculator was employed [35]. Temperature, precipitation, and atmospheric $\mathrm{CO}_{2}$ concentrations for climate scenarios are presented in Table 1. Inputs for soil physical properties, planting, fertilization, and tillage operations were obtained from Ramnarine et al. [36] and Gaudin et al. [37].

The water flow submodel simulates the daily flow of water through the plant canopy, litter, and soil layers. Transpiration is calculated after water has been redistributed in the soil. The sum of sublimation, interception, soil evaporation, and transpiration does not exceed the daily potential evapotranspiration (PET) rate. The potential daily evapotranspiration rate (PET) is calculated as a function of the average daily air temperature. The soil water submodel simulates above field capacity water content, unsaturated water flow using Darcy's equation, runoff, snow dynamics, and the effects of soil freezing on saturated water flow. Each soil layer is assigned unique properties including thickness, field capacity, wilting point, proportion of roots, bulk density, soil texture (percent sand and clay), saturated hydraulic conductivity, minimum soil water content, and soil $\mathrm{pH}$. These values are based on observed data from each site or estimates based on soil texture at the site. Leaching occurs when there is water flow between soil layers. The fraction of the mineral pool that flows from the upper layer to the lower layer increases with increasing sand content and water flow [38]. 
Table 1. Predicted air temperatures $\left({ }^{\circ} \mathrm{C}\right)$, precipitation (mm) and air $\mathrm{CO}_{2}$ concentrations (up to 2100) for two representative concentration pathways (RCP 4.5 and 8.5) for Elora, ON, Canada. [34,39]. $(t$ max $=$ temperature maximum, $t$ min $=$ temperature minimum, prec $=$ precipitation $)$.

\begin{tabular}{|c|c|c|c|c|c|c|c|c|}
\hline \multirow{2}{*}{$\begin{array}{l}\text { Climate } \\
\text { Scenario }\end{array}$} & \multicolumn{4}{|c|}{ RCP 4.5} & \multicolumn{4}{|c|}{ RCP 8.5} \\
\hline & $t \max$ & $t \min$ & prec & $\mathrm{CO}_{2}$ & $t \max$ & $t \min$ & prec & $\mathrm{CO}_{2}$ \\
\hline Decade & \multicolumn{2}{|c|}{$\left({ }^{\circ} \mathrm{C}\right)$} & $(\mathrm{mm})$ & $\left(\mathrm{mg} \mathrm{m}^{-3}\right)$ & \multicolumn{2}{|c|}{$\left({ }^{\circ} \mathrm{C}\right)$} & $(\mathrm{mm})$ & $\left(\mathrm{mg} \mathrm{m}^{-3}\right)$ \\
\hline $2011-2020$ & 11.9 & 2.9 & 912 & 382 & 12.0 & 2.8 & 908 & 382 \\
\hline $2021-2030$ & 12.5 & 3.4 & 965 & 409 & 12.9 & 3.7 & 1030 & 437 \\
\hline 2031-2040 & 13.0 & 3.8 & 1065 & 427 & 13.1 & 4.1 & 969 & 504 \\
\hline $2041-2050$ & 13.1 & 3.9 & 1030 & 444 & 13.9 & 4.7 & 1042 & 571 \\
\hline $2051-2060$ & 13.3 & 4.3 & 987 & 461 & 14.3 & 5.3 & 1106 & 637 \\
\hline $2061-2070$ & 13.6 & 4.7 & 995 & 478 & 15.1 & 5.9 & 1049 & 704 \\
\hline 2071-2080 & 14.2 & 5.2 & 1039 & 496 & 15.8 & 6.7 & 1085 & 771 \\
\hline 2081-2090 & 14.4 & 5.3 & 1058 & 513 & 16.3 & 7.4 & 1045 & 838 \\
\hline $2091-2100$ & 14.7 & 5.5 & 1012 & 530 & 17.7 & 8.5 & 1016 & 905 \\
\hline
\end{tabular}

\subsection{DayCent: Initialization and Calibration for Crop Rotation and WSGs}

\subsubsection{Initialization}

Initialization of DayCent requires a long-term spin-up simulation (e.g., millennia) to bring the soil organic carbon pools to a steady state [40]. The initial SOC pools $(0-20 \mathrm{~cm}$ depth) were generated by 1900 years of spin-up simulation of a temperate mixed forest followed by simulation of historical land/cover use data; 70 years of low intensity agriculture (1911-1980), and since 1981 a CCSW rotation field experiment (Table 2).

Table 2. Land use history data for Elora, ON. Canada, applied in DayCent simulations.

\begin{tabular}{cc}
\hline Forest and Cropping System & Years \\
\hline Temperate_Mixed_Forest & $0-1910$ \\
Deforestation & 1911 \\
Corn-Barley & $1912-1958$ \\
Continuous corn & $1959-1980$ \\
Corn-corn-soybean-winter wheat & $1981-2008$ \\
Corn-corn-soybean-winter wheat & $2009-2100$ \\
Switchgrass & $2009-2100$ \\
Miscanthus & $2009-2100$ \\
\hline
\end{tabular}

Land-use changes for the southern Ontario region has been described in studies by Larson et al. [41].

\subsubsection{Parametrization}

The weather files for future climate scenarios at Elora, ON, Canada were generated by using the regional climate model CanRCM4 [39,42]. Crop files for switchgrass and miscanthus were created by modification of the warm season (C4) grass species file. Switchgrass, a native to North America, has wide adaptation due to inherent genotypic variation within switchgrass populations and cultivars [43]. Miscanthus is a high-yielding perennial grass native to Asia [44] and it has a higher yield potential than switchgrass $[45,46]$. Plantings are clonal, therefore plants within a cultivated population lack genotypic variability. Heaton et al. [45] reported that miscanthus showed a stronger response to water, while switchgrass showed a significantly higher response to nitrogen. The calibration of WSG growth parameters were based on data from an experiment conducted in Elora [12]. For all simulations, the non-growing degree day option was implemented. Since DayCent reports above-ground biomass production in units of $\mathrm{g} \mathrm{C} \mathrm{m}^{-2}$, predictions were converted to $\mathrm{Mg} \mathrm{ha}^{-1}$ assuming a plant $\mathrm{C}$ content of $46 \%$ for both species $[46,47]$. 


\subsubsection{Validation}

CCSW calibration and validation was performed by comparisons of DayCent predictions versus measured crop grain yields. For the CCSW rotation simulations, DayCent was set for grain harvest with $50 \%$ crop residue removal. Switchgrass and miscanthus crops were calibrated based on measurements of plant biomass from an experiment at Elora [12]. WSGs simulations were fall harvested and set for removal of $75 \%$ of the aboveground biomass.

\subsubsection{Simulation 2009-2100}

Although both switchgrass and miscanthus stands can be productive for longer than 10 years [48,49], a 10-year stand rotation was chosen to simplify the simulation and to provide more opportunity in the model for root biomass turnover. In the 10th year since planting, after the 10th annual harvest, a plowing event was created and new stands of WSGs were planted in the subsequent spring. All simulations were performed for RCP 4.5 and 8.5 scenarios.

\subsection{Statistical Evaluation}

Comparisons between observed data and DayCent predicted values were evaluated using the following statistical tests: mean absolute percentage error (MAPE, \%) and root mean squared error (RMSE). Jamieson et al. [50] presented a performance measurement scale using the MAPE: if MAPE $<10$ - excellent; <20-good; <30-fair; and >30-poor.

The formulas for the MAPE and RMSE are defined as follows:

$$
\mathrm{MAPE}=\frac{100 \%}{n} \sum_{t=1}^{n} \frac{a_{t}-p}{a_{t}}
$$

where $a_{t}$ is the observed value of the quantity being forecasted, $p$ is the predicted value and $n$ is the number of observations.

$$
\mathrm{RMSE}=\left[n^{-1} \sum_{i=1}^{n}\left(p-a_{t}\right)^{2}\right]^{0.5}
$$

Confidence interval (C.I.) for SOC data at $p=0.05$ were computed using equation (3):

$$
\text { C.I. }=\bar{x} \pm t \cdot \frac{s}{\sqrt{n}}
$$

where $\bar{x}$ is sample mean, $t$ is confidence coefficient, $s$ is standard deviation of the mean and $n$ is the sample size.

Relationships between WSGs biomass production and SOC stocks were estimated with a Pearson correlation coefficient $(r)$. Nonlinear regressions and fitting regression lines based on DayCent predictions of SOC and were performed using SigmaPlot Version 11.0.

\section{Results}

Weather data for future projections showed increased temperatures with RCP 8.5 compared to RCP 4.5 of 13.1 and $10.1^{\circ} \mathrm{C}$ by 2100 , respectively. However, precipitation underwent fluctuations, but they were not connected with time frame or RCP scenarios (Table 1, Figure 1). CCSW crop yields were validated against recorded crop data for 1981-2015 (Table 3). Statistical evaluators RMSE and MAPE showed that predicted and observed switchgrass and miscanthus biomass was in close agreement with 2.9 and 2.7\% MAPE, respectively. RMSE and MAPE for crops corn, soybean and winter wheat were also in good or satisfactory agreement with field data: 18.2, 24.7 and 23.9\% MAPE, respectively (Table 3). The SOC stock (0 to $20 \mathrm{~cm}$ ) in the CCSW rotation, before converting to WSGs in 2008, was predicted by DayCent to be $56.2 \mathrm{Mg} \mathrm{ha}^{-1}$. This value is in agreement with available observed SOC data; an average from 1998 and 2000 was 54.2 (3.7) $\mathrm{Mg} \mathrm{ha}^{-1}$. DayCent estimation for the same period was $54.8(0.8) \mathrm{Mg} \mathrm{ha}^{-1}$. From a SOC stock of $95 \mathrm{Mg}$ ha $^{-1}$ in 1913 stocks (Figure 2) levels declined after 
deforestation and the land was converted to agricultural use (Figure 2, Table 4). DayCent predicted that over the next 85 years with annual crop rotations, SOC stocks were reduced by $41 \%\left(56 \mathrm{Mg} \mathrm{ha}^{-1}\right.$ in 2008) (Table 4). If the CCSW rotation is maintained, DayCent predicted SOC stocks would remain steady (Figure 2a). Over the 21st century, a slight increase in CCSW SOC $\left(\sim 30 \mathrm{~kg} \mathrm{ha}^{-1} \mathrm{yr}^{-1}\right)$ was predicted in the RCP 4.5 scenario (Figure 2a, Table 4). Increases in SOC stocks were predicted in both grasses (Figure 2b,c, Table 4). At the end of 21st century, for RCP 4.5 scenario, DayCent predicted $79.5 \mathrm{Mg} \mathrm{ha}^{-1}$ SOC stock for switchgrass and $144.0 \mathrm{Mg} \mathrm{ha}^{-1}$ for miscanthus, which is 84 and $151 \%$ of the original SOC stocks, respectively (Figure 2b,c, Table 4). For 8.5 scenario, at the second half of 21st century, there was a predicted decline in SOC stock in the miscanthus system (Figure 2b,c, Table 4). In 2060, when both grasses were switched back to a CCSW rotation, the model predicted a rapid decline in previously sequestered SOC for both WSG systems. Prediction of SOC stocks in 2100 in SG-CCSW was $63.5 \mathrm{Mg} \mathrm{ha}^{-1}$ and in MIS-CCSW was $79.6 \mathrm{Mg} \mathrm{ha}^{-1}$ (Figure 2b,c and Table 4 in RCP 4.5). As in all previous cases the decline in SOC was greater in the RCP 8.5 scenario (Figure 2, Table 4).

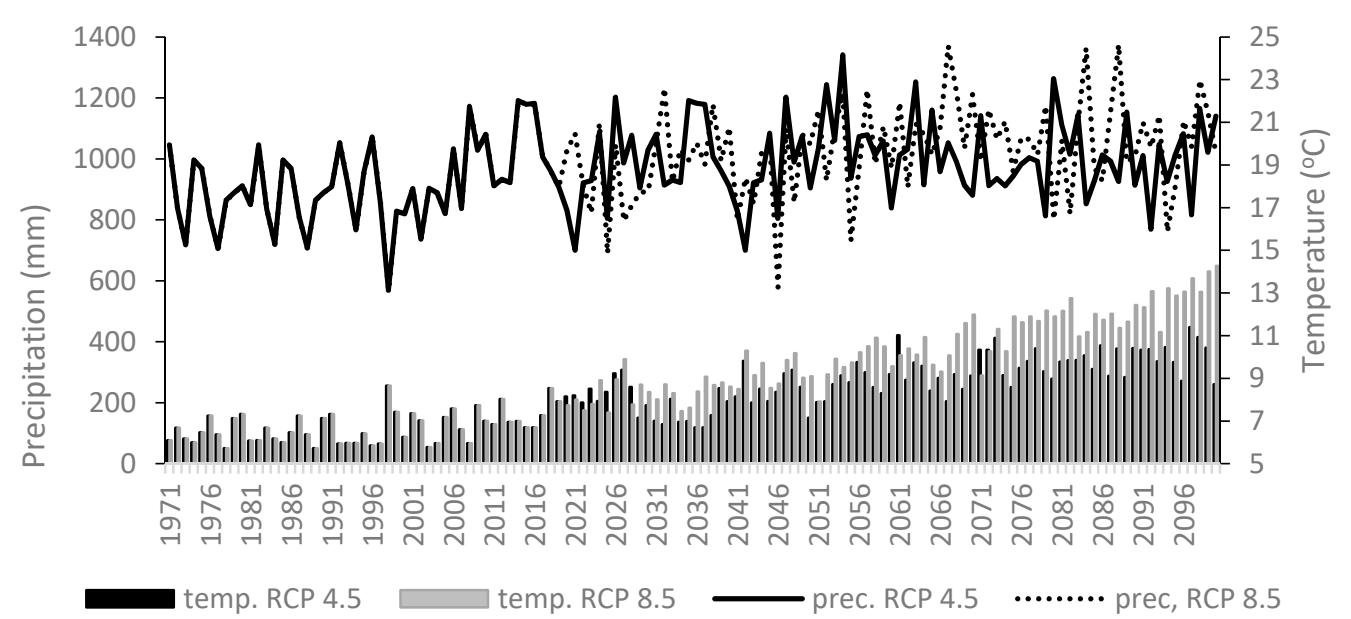

Figure 1. Predicted total annual precipitation $(\mathrm{mm})$ and average annual temperature $\left({ }^{\circ} \mathrm{C}\right)$ for two representative concentration pathways: RCP 4.5 and 8.5 during 1971-2100.

Table 3. Observed and predicted crop yields and crop yield validation.

\begin{tabular}{|c|c|c|c|c|c|c|c|c|}
\hline \multirow{2}{*}{ Crop } & & \multirow{2}{*}{$\mathbf{n}$} & Yield & $\begin{array}{c}\mathrm{CL}^{\#} \\
p=0.05\end{array}$ & St Dev & $\begin{array}{c}\text { St } \\
\text { Error }\end{array}$ & RMSE $\$$ & \multirow{2}{*}{$\begin{array}{c}\text { MAPE \& } \\
(\%)\end{array}$} \\
\hline & & & \multicolumn{5}{|c|}{$\longrightarrow\left(\mathrm{kg} \mathrm{ha}^{-1}\right)$} & \\
\hline \multirow{2}{*}{ Corn Grain } & observed & 35 & 8770 & 613 & 1786 & 302 & \multirow{2}{*}{1936} & \multirow{2}{*}{18.6} \\
\hline & predicted & 35 & 8600 & 632 & 1842 & 311 & & \\
\hline \multirow{2}{*}{ Soybean Grain } & observed & 17 & 2874 & 277 & 539 & 131 & \multirow{2}{*}{872} & \multirow{2}{*}{24.7} \\
\hline & predicted & 17 & 2511 & 369 & 719 & 174 & & \\
\hline \multirow{2}{*}{ Winter Wheat Grain } & observed & 18 & 5101 & 379 & 763 & 180 & \multirow{2}{*}{1547} & \multirow{2}{*}{23.9} \\
\hline & predicted & 18 & 4885 & 594 & 1176 & 277 & & \\
\hline \multirow{2}{*}{$\begin{array}{c}\text { Switchgrass } \\
\text { Biomass }\end{array}$} & observed & 2 & 9420 & 1500 & 167 & 118 & \multirow{2}{*}{278} & \multirow{2}{*}{2.9} \\
\hline & predicted & 2 & 9446 & 209 & 23 & 16 & & \\
\hline \multirow{2}{*}{ Miscanthus Biomass } & observed & 2 & 20940 & 2893 & 322 & 228 & \multirow{2}{*}{661} & \multirow{2}{*}{2.7} \\
\hline & predicted & 2 & 20376 & 1178 & 132 & 93 & & \\
\hline
\end{tabular}

\footnotetext{
${ }^{\#} \mathrm{CL}=$ confidence level at $p=0.05 ;{ }^{\$} \mathrm{RMSE}=$ root mean square error; ${ }^{\&} \mathrm{MAPE}=$ mean absolute percentage error
} 

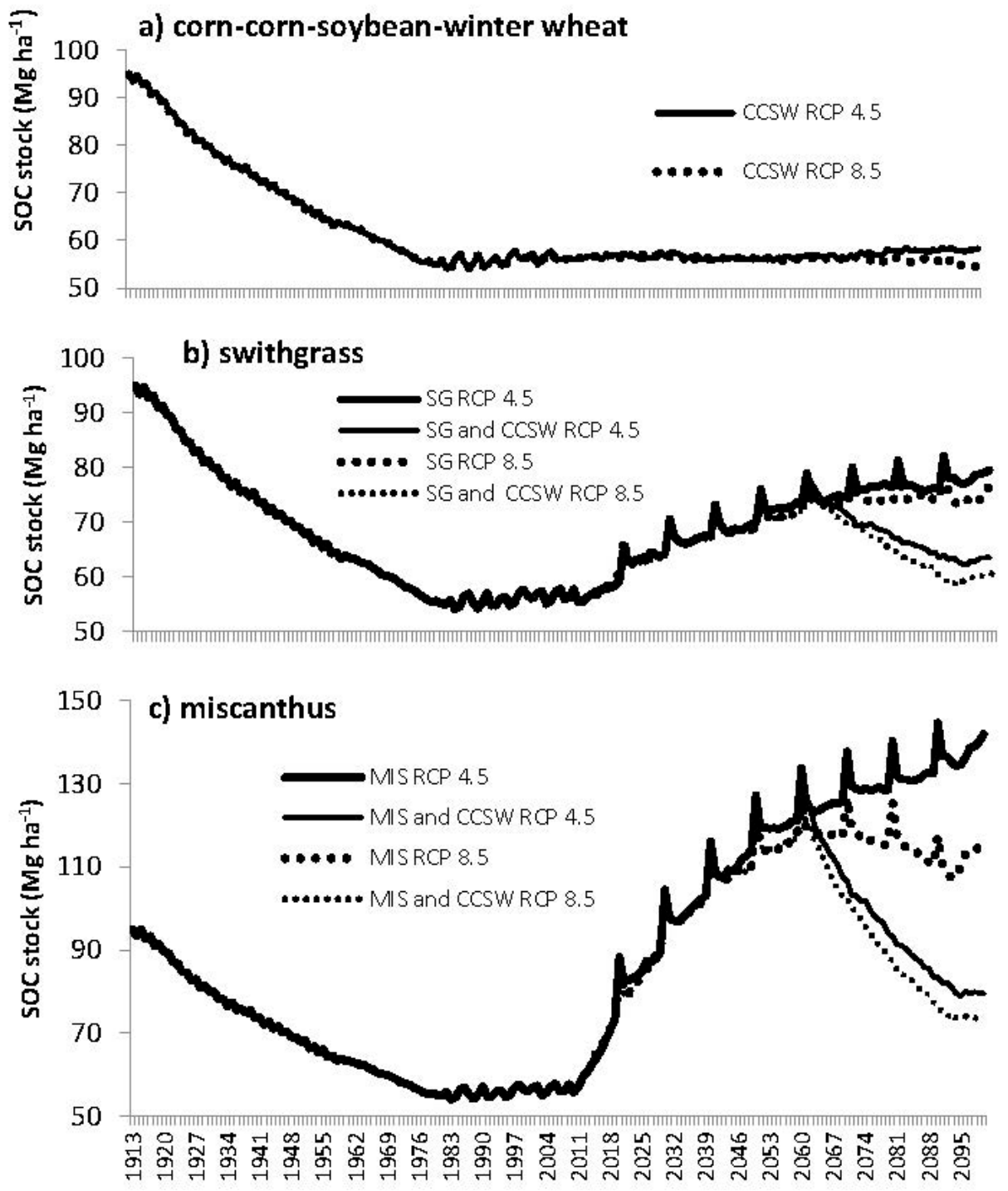

Figure 2. Soil organic carbon (SOC) dynamics over 1913-2100 in corn-corn -soybean-winter wheat (a), switchgrass (b) and miscanthus (c) cropping systems, predicted by DayCent in $20 \mathrm{~cm}$ soil layer for two representative concentration pathways: RCP 4.5 and 8.5. CCSW = corn-corn-soybean-winter wheat; SG = switchgrass; MIS = miscanthus.

Table 4. Soil organic carbon (SOC) stock $\left(\mathrm{Mg} \mathrm{ha}^{-1}\right)$ over 21st century under corn-corn-soybean-winter wheat ${ }^{\#}(\mathrm{CCSW})$, switchgrass and miscanthus.

\begin{tabular}{|c|c|c|c|c|c|c|}
\hline Scenario & Year & CCSW & Sw & rass & Mis & thus \\
\hline \multirow{4}{*}{$\mathrm{RCP} 4.5$} & 1913 & \multicolumn{5}{|c|}{$94.9(100)$} \\
\hline & 2008 & \multicolumn{5}{|c|}{$56.2(59)$} \\
\hline & 2060 & $57.0(60)$ & \multicolumn{2}{|c|}{$78.9(83)$} & \multicolumn{2}{|c|}{$133.7(140)$} \\
\hline & 2100 & $56.2(59)$ & $79.5(84)$ & $63.5(67)^{\&}$ & $144.0(151)$ & $79.6(84) \&$ \\
\hline \multirow{2}{*}{ RCP 8.5} & 2060 & $55.0(58)$ & \multicolumn{2}{|c|}{$77.8(82)$} & \multicolumn{2}{|c|}{126.58} \\
\hline & 2100 & $55.0(58)$ & $76.9(81)$ & $60.6(64)^{\&}$ & $124.9(132)$ & $73.7(78) \&$ \\
\hline
\end{tabular}

Numbers in parentheses express the SOC as a percentage of original SOC stock at the deforestation; ${ }^{\#} \mathrm{CCSW}$; Final SOC stock after switching back grasses to annual crop cultivation in 2061.

Lines presented on Figure 2 show changes in SOC stock over 20th and 21st century. In the first 50 years after deforestation, under low intensity agriculture constant decline in SOC stock was observed (Figure 2a-c). Then from 1981, when CCSW was introduced the SOC stock remained on 
similar level until 2100 (Figure 2a). After changing crop rotation (CCSW) to WSG there was a observed rapid increase in SOC stock until the end of 21st century with RCP 4.5 for both grasses and for RCP 8.5 for SG, and some decline for MIS in the last 40 years of simulation (Figure 2b,c). In the middle of the 21st century, when land with WSG was converted back to CCSW, the SOC stock declined (Figure 2b,c) and after about 50 years dropped to the level observed prior to the conversion to WSG (Figure 2a). Perennial WSG systems are characterized by continuous biomass production with low soil and underground biomass disturbance. Large input of biomass with slower turnover rates can result in enhanced SOC sequestration. Similar gains in SOC sequestration was observed by Garten [51] for switchgrass and by Poeplau and Don [52] in the case of miscanthus. However, conversion of WSG to CCSW can reduce biomass inputs and lead to increased turnover rate and thereby contribute to ongoing reduction of SOC sequestration and result in previous SOC level as observed under CCSW rotation.

Switchgrass biomass production was positively correlated with SOC stocks for both RCP 4.5 and 8.5, whereas miscanthus biomass was correlated only for the RCP 4.5 scenario (Table 5). Miscanthus biomass in RCP 8.5 over the last four decades of the 21st century tended to be lower than at RCP 4.5 (Figure 3).

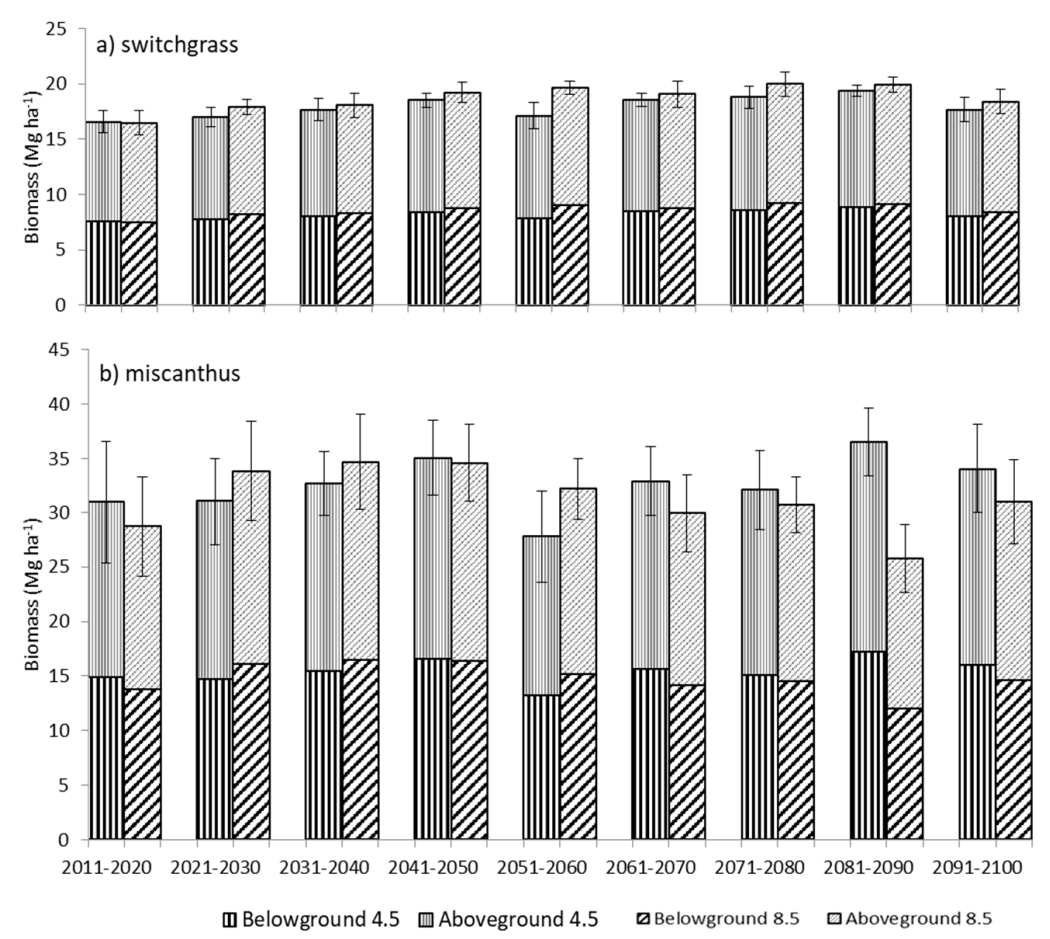

Figure 3. Average decadal switchgrass and miscanthus below and aboveground biomass production predicted by DayCent over the 21st century at two representative concentration pathways: (a) RCP 4.5 and (b) RCP 8.5. Error bars represent confidence level for sum above and below ground biomass at $p=0.05$.

Table 5. Pearson correlation coefficients between above and below biomass and SOC stocks (ns = non-significance).

\begin{tabular}{ccccc}
\hline \multirow{2}{*}{ Biomass } & \multicolumn{2}{c}{ Switchgrass } & \multicolumn{2}{c}{ Miscanthus } \\
\cline { 2 - 5 } & SOC at RCP 4.5 & SOC at RCP 8.5 & SOC at RCP 4.5 & SOC at RCP 8.5 \\
\hline Aboveground & $0.70^{*}$ & $0.87^{* *}$ & $0.61^{*}$ & Ns \\
Belowground & $0.72^{*}$ & $0.87^{* *}$ & $0.63^{*}$ & Ns \\
Above + Belowground & $0.71^{*}$ & $0.87^{* *}$ & $0.64^{*}$ & Ns \\
\hline
\end{tabular}

${ }^{*}$ indicates significant relationship at $p=0.05 ; * *$ indicates significant relationship at $p=0.01$. 
For switchgrass, there were no significant differences between RCP 4.5 and 8.5 in sum of below and above ground biomass production, with exception of 2051-2060 when more biomass was produced by RCP 8.5. This period corresponds when there was more precipitation on RCP 8.5 than on RCP 4.5 (Table 1). Similar to predictions for switchgrass, miscanthus did not show differences in biomass production between RCP 4.5 and 8.5 with the exception of 2081-2090, when more biomass was predicted on RCP 4.5 than on RCP 8.5 (Figure 3). It can be attributed to an increase in air temperature and associated with its higher response to water. However, in the next decade (2091-2100) this was not predicted to occur (Figures 1 and 3).

After switching from a CCSW rotation to WSGs, DayCent predicted a rapid increase in SOC until the mid of 21st century (Figure 4a,b). In the second half of the 21st century, SOC stocks were predicted to remain at the same level for RCP 4.5 for both grasses (Figure 3a). However, for RCP 8.5, the model predicted decreases in SOC stocks for miscanthus during the 2nd half of the 21st century (Figure 4a,b).
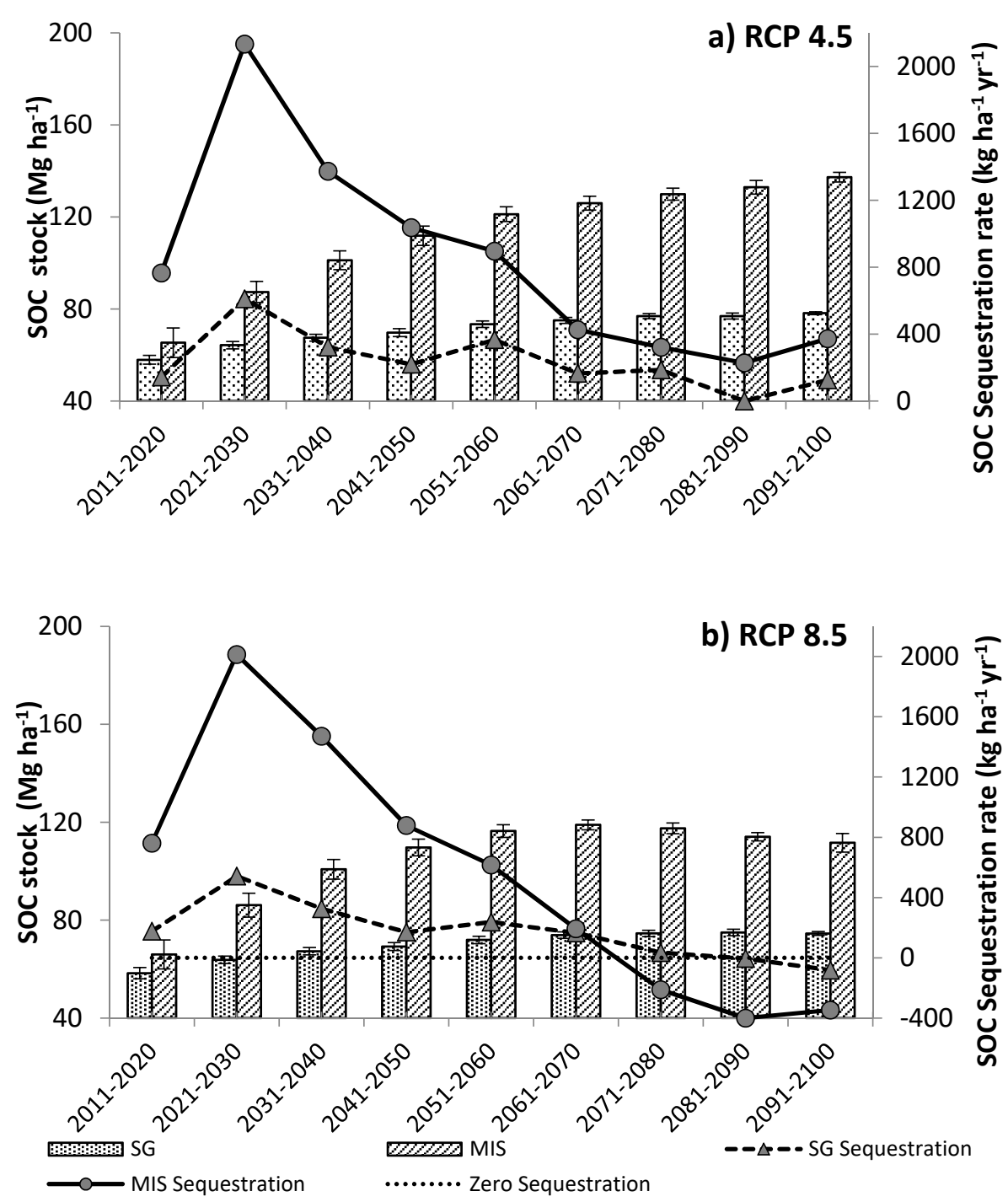

Figure 4. Average decadal SOC stocks and SOC sequestration rates for $20 \mathrm{~cm}$ soil layer from DayCent prediction for two representative concentration pathways: (a) RCP 4.5 and (b) RCP 8.5. MIS = miscanthus; SG = switchgrass; MIS = miscanthus sequestration $=$ SOC sequestration under miscanthus, SG sequestration $=$ SOC sequestration under switchgrass; Zero sequestration $=$ no sequestration over the recent decade; Error bars represent confidence level at $p=0.05$. 
Examination of SOC sequestration rates over subsequent decades showed that the highest sequestration rates were in the first 20 years after the introduction of WSGs at 2.13 and $0.61 \mathrm{Mg} \mathrm{C} \mathrm{ha}^{-1} \mathrm{yr}^{-1}$ for miscanthus and switchgrass, respectively (Figure 4). Over time when SOC stocks tended to stabilize, SOC sequestration rates from decade to decade were reduced to zero for switchgrass and to $0.23 \mathrm{MgC} \mathrm{ha}^{-1} \mathrm{yr}^{-1}$ for miscanthus in the decade of 2080-2090 (Figure 4a). The decline in SOC stocks in a RCP 8.5 scenario in the second half of the 21st century was mainly due to the absence or negative SOC sequestration rate over last three decades (Figure $4 b$ ). However, the average SOC sequestration rate over the entire period of the simulation (2009-2100) with RCP 4.5 scenario remained at 0.26 and $0.94 \mathrm{MgC} \mathrm{ha}^{-1} \mathrm{yr}^{-1}$, for switchgrass and miscanthus, respectively (Figure 5). With a RCP 8.5 scenario, SOC sequestration rates were predicted to be lower at 0.23 and $0.64 \mathrm{MgC} \mathrm{ha}{ }^{-1} \mathrm{yr}^{-1}$ for switchgrass and miscanthus, respectively (Figure 5). Such sequestration rates exceed or approach the threshold of minimum mitigation requirement (MMR, $0.25 \mathrm{Mg} \mathrm{Cha}^{-1} \mathrm{yr}^{-1}$ ) (Figure 5).

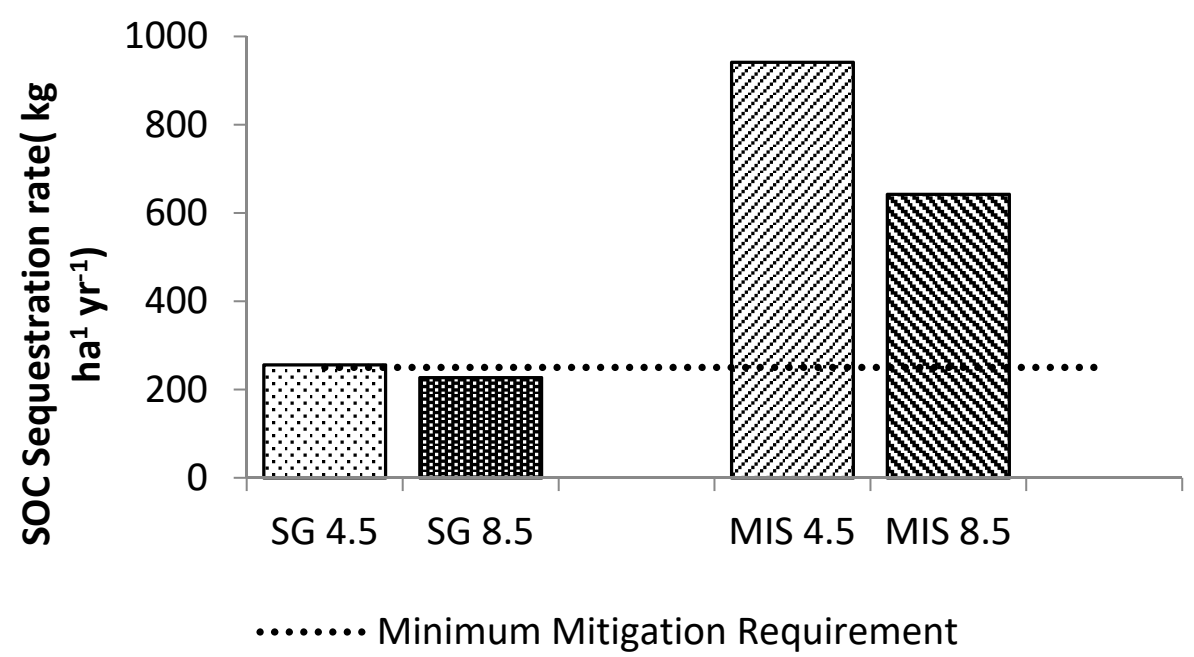

Figure 5. DayCent predicted average SOC sequestration rate over the entire simulation period (2009-2100). SG $4.5=$ switchgrass at RCP 4.5; SG 8.5 = switchgrass at RCP 8.5; MIS $4.5=$ miscanthus at RCP 4.5; MIS 8.5 = miscanthus at RCP 8.5.

Decadal SOC stock changes over the 21st century were fitted to non-linear regression lines (Figure 6). For a RCP 4.5 scenario, the best fit for switchgrass and miscanthus was described as nonlinear regression and an exponential rise to maximum values (Figure 6a,b). For an RCP 8.5 scenario, the best fit for switchgrass was also nonlinear regression, exponential rise to maximum (Figure 6a). With RCP 8.5 for miscanthus, a nonlinear regression was fitted to a hyperbolic line (Figure $6 \mathrm{~b}$ ), which was because of a prediction that SOC carbon stocks would decline during the second half of 21st century (Figures 2, 4 and 6). 

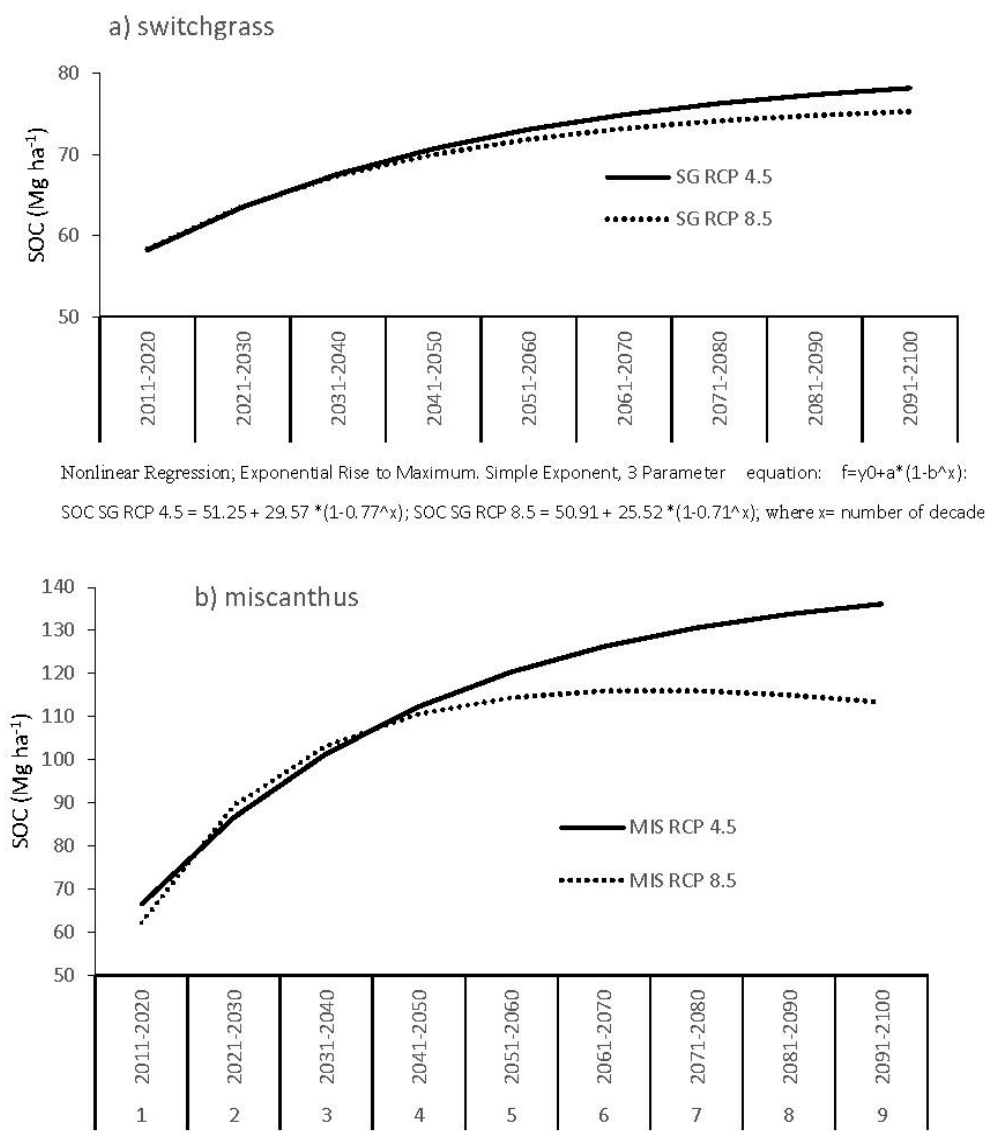

MIS RCP 4. 5: Nonlinear Regression; Exponential Rise to Maximum. SOCMIS RCP $4.5=38.99+103.6^{*}\left(1-0.73^{\wedge} x\right)$ MIS RCP 8.5: Nonlinear Regression; Equation: Hyperbola, Single Rectangular I, 3 Parameter $\mathrm{f}=\mathrm{a} * \mathrm{z} /(\mathrm{b}+\mathrm{x})+\mathrm{c} * \mathrm{x}$. SOC MIS RCP $8.5=190.5 *$ * $/\left(1.83+(-4.9887)^{2} \mathrm{x}\right.$; where $\mathrm{x}=$ number of decade

Figure 6. Soil organic carbon stocks. Nonlinear regressions for switchgrass (a) and miscanthus (b) based on DayCent prediction over investigated period.

\section{Discussion}

Biomass growers in Ontario, Canada have a shared goal in developing beneficial management strategies to further enhance the profitability and environmental sustainability of their industry. Thus, they are keen to understand the impacts of land-use change from low-productive conventional agriculture to WSGs (switchgrass and miscanthus) and from WSGs to conventional agriculture on soil organic carbon (SOC) sequestration. Focusing on this need, our study was designed to analyze the SOC dynamics as influenced by land-use changes using the DayCent model. Biomass yields and SOC data were used from a single long-term biomass experimental site situated in Elora, ON, Canada.

Presented research revealed the potential of WSGs to sequester SOC in the 21st century time frame under a moderate warming scenario (RCP 4.5). The nonlinear regression suggests that the SOC sequestration will extend beyond the 21st century. Such results were expected as per short-term published experimental data [51,52]. These data confirmed the high SOC sequestration in WSG resulting from large above and below ground biomass under 8-10-year cycle in undisturbed soil. The simulation results in this study also confirmed our assumption that field crop rotation (CCSW) would maintain a steady level of SOC over the 21st century. However, the lack of knowledge on the time that will take to deplete the gained SOC under WSGs to pre-WSG establishment level when WSGs stands are converted back to field crop rotation is now addressed by this study. Our modelling study has estimated that this process would take $40-50$ years. Under high warming scenario (RCP 8.5) WSG biomass production and SOC are supposed to be decreased due to high air temperature with average amount of precipitation. Our results over the 21st century did not confirm this supposition. However, 
nonlinear regression in our study suggests that with higher temperatures in RCP 8.5, such impact can be possible in the longer time frame (>100 years). Negative physiological processes such as stomatal resistance under elevated temperature conditions may cause lower photosynthesis in WSG. This in turn may result in low biomass production and residue inputs to the soil contributing to low SOC accumulation (Figure 6).

DayCent predicted $41 \%$ reduction in SOC stock over 85 years after conversion of the native forest to agricultural row crop cultivation. Based on experimental data obtained from the Great Plains, [53] reported a 41\% reduction in upper layer SOC stocks after 40 years of annual grain cropping. Compared to pre-cultivation and annual cropping, computer models estimated a $35 \%$ reduction in SOC stocks for Canadian prairie soils [54].

DayCent prediction of high WSGs biomass productivity supports Kludze [2] findings in which stated that Ontario has an adequate land base for production of switchgrass or miscanthus. Using model predictions, Barney and DiTomaso [55] and Hager et al. [56] investigated the habitat suitability for switchgrass and miscanthus with various climate change scenarios and showed that WSGs are suitable to grow in a wide range of habitats throughout the Northern Hemisphere. With a moderate climate warming (RCP 4.5), predicted SOC equilibrium under WSGs is expected after 40-50 years, whereas under high climate warming (RCP 8.5) it is expected after 30-40 years. At this time, there are no comparable data to evaluate the declining of SOC when WSGs are converted to annual crops. However, our study shows that after 40 years of growing WSGs, if the WSG lands are converted to annual crops, the SOC sequestered under WSG production will be lost in 40-50 years.

Generally, predicted WSGs biomass was correlated with SOC stocks with the exception for miscanthus at RCP 8.5, which can be attributed to minor variations in SOC stock in relation to large fluctuation in miscanthus biomass yields.

\subsection{SOC Sequestration Rate}

In our study the predicted SOC sequestration rate over the end of the 21st century was higher under miscanthus than under switchgrass (0.94 vs. $0.26 \mathrm{Mg} \mathrm{C} \mathrm{ha}^{-1} \mathrm{yr}^{-1}$ in RCP 4.5 , respectively) due to larger above and below miscanthus biomass production (Figure 3a,b). Agostini et al. [13] compared SOC sequestration rates from 12 miscanthus and 9 switchgrass experiments and reported mean values 1.21 and $1.59 \mathrm{Mg} \mathrm{C} \mathrm{ha}^{-1} \mathrm{yr}^{-1}$ for miscanthus and switchgrass, respectively. However, a high SOC sequestration rate of $1.98 \mathrm{MgC} \mathrm{ha}^{-1} \mathrm{yr}^{-1}$ was reported for miscanthus by Nakajima et al. [57]. The SOC sequestration rate can be altered by several factors including duration of the trial, soil texture and initial SOC stock. Higher SOC sequestration rates can be observed in sandy soils compared to clay soils. When converted to WGS, compared to perennial grasslands, arable soils show higher SOC sequestration rates due to their lower initial SOC stocks [13]

\subsection{Climate Scenarios}

Hager et al. [56] pointed out that future predictions should be made using a high emission scenario, where a reduction in crop yields and a decline in SOC can be expected. Robertson et al. [24] reported a decline in DayCent simulated crop yields under a RCP 8.5 scenario after 2050 over the 21st century. However, the increase in SOC stocks for perennial grassland treatments was noticed through 2100, even under RCP 8.5, with an exception under RCP 4.5 scenario, where SOC stocks were consistently higher than RCP 8.5 though the differences were small [24]. In our study, under switchgrass for both RCP 4,5 and 8.5, the SOC stocks increased until 2060 and then plateaued until 2100. Nevertheless, under miscanthus the increase in SOC stocks was predicted only under RCP 4.5. Robertson et al. [24] hypothesized that as temperature increased, crop yields would decline, SOC decomposition would increase, and reduce SOC sequestration at the end of 21st century. The nonlinear regression for both grasses, at RCP 4.5 and for switchgrass at RCP 8.5, shows that SOC stocks will stay at the same level after reaching equilibrium, whereas for miscanthus at RCP 8.5 SOC stocks will decline over time. 


\subsection{Potential Shortcoming in this Study}

The model simulation results presented in this study accounted for field conditions in Southern Ontario; however, it is a challenge to capture all the complex biophysical interactions that are in operation in WGS ecosystems. Del Grosso et al. [58] reported that most of the errors in DayCent model outputs are associated with imperfections in model algorithms and parameters, as opposed to uncertainty in model drivers. Therefore, efforts to improve the model should concentrate on comparing model outputs using numerous observations for various $\mathrm{C}$ and $\mathrm{N}$ components from field experiments to identify weaknesses and thereby rectify model shortcomings. In this context, the present study used data from one single research site due to lack of long-term data for warm season biomass grass and agricultural crops from different fields in Ontario, Canada. Further testing and improvement of model algorithms and parameters is therefore expected to increase accuracy and reliability of model outputs at various scales as reported by Del Grosso et al. [58].

In addition, difficulties in obtaining reliable data have been a major challenge in model parametrization. Typically, models are parameterized using the data from literature review [51] or farmers' field documentation and sampling [52]. In our model parameterization, we used crop, soil and weather data derived from long term field experiments, which is the most desirable type of data to reduce the uncertainty associated with model parameterization. However, as indicated above, a wide range of field data are required to further fine-tune model predictions in relation to SOC sequestration.

Based on the literature, we assumed that introducing WSG would lead to increase in SOC sequestration in comparison with annual crop rotation. The most uncertain is vegetation of WSG and field crops in RCP 8.5 scenario. There was expected strong decline in biomass production and SOC content, but only some tendency was observed over 21st century. Authors recognize that under RCP 8.5 scenario, biomass production from WSG or field crops is highly uncertain; however, the RCP 8.5 scenario was used in the model simulation to comply with policy formation requirement and IPCC guidelines.

\section{Conclusions}

Based on DayCent predictions, a CCSW rotation avoided further SOC depletion, and a potential to sequester SOC under WSGs production. Predicted above and below ground biomass was higher for miscanthus than for switchgrass and this resulted in higher SOC sequestration rates under miscanthus. The high rate of SOC sequestration was predicted to occur during the first 20-30 years of planting WSGs. SOC levels tended to stabilize by 50-60 years of converting to WSGs. However, SOC stocks under a moderate warming RCP 4.5 scenario were characterized by a nonlinear regression exponential rise to maximum values. Under a high warming scenario, RCP 8.5 DayCent predicted that SOC stocks would decline in a miscanthus stand after 50 years. Nevertheless, the rate of SOC sequestration at the end of 21st century at RCP 4.5 was 0.94 and $0.26 \mathrm{Mg} \mathrm{C} \mathrm{ha}^{-1} \mathrm{yr}^{-1}$ for miscanthus and switchgrass, respectively, which exceeded the minimum mitigation rate for energy crops $\left(0.25 \mathrm{Mg} \mathrm{C} \mathrm{ha}^{-1} \mathrm{yr}^{-1}\right)$. Sequestered SOC can be readily lost when WSG stands are converted back to row crop cultivation. In such case, the SOC sequestered over 40-50 years with WSGs production would decline with annual cropping within 50 years back to levels prior to the introduction of switchgrass and miscanthus. DayCent simulations predict that under a high warming RCP 8.5 scenario in the second half of the 21st century and in the future, we can expect reductions in SOC stocks especially under miscanthus stands.

Author Contributions: Conceptualization, M.J., K.K., J.G., P.V. and N.T.; Methodology, M.J., K.K., and J.G.; Software, M.J., K.K., and J.G.; Validation, M.J.; Formal analysis, M.J., K.K., and J.G.; Investigation, M.J., K.K., B.D., J.G., A.B.B., S.V., P.V., M.T., A.G., and N.T.; Data curation, M.J., K.K., J.G., B.D., M.T., and S.V.; Writing-original draft preparation, M.J., and K.K.; Writing—review and editing, B.D., J.G., A.B.B., S.V., P.V., M.T., A.G., and N.T.; Visualization: M.J., and A.B.B.; Supervision: N.T., and P.V.; Project administration, N.T.; Funding acquisition: N.T. All authors have read and agreed to the published version of the manuscript. 
Funding: This research was funded by the Ontario Ministry of Agriculture, Food and Rural Affairs (OMAFRA); Grant Number 0301-82.

Acknowledgments: The authors would like to thank the Ontario Ministry of Agriculture, Food and Rural Affairs (OMAFRA) and the members of the Ontario Biomass Producer Cooperative (OBPC) for their continued support towards biomass research in the province of Ontario, Canada.

Conflicts of Interest: The authors declare no conflict of interest.

\section{References}

1. Pachauri, R.K.; Mayer, L. Intergovernmental Panel on Climate Change. In Climate Change 2014: Synthesis Report; Contribution of Working Groups I, II and III to the Fifth Assessment Report of the Intergovernmental Panel on Climate Change; IPCC: Geneva, Switzerland, 2014; ISBN 9789291691432.

2. Kludze, H.; Deen, B.; Weersink, A.; van Acker, R.; Janovicek, K.; De Laporte, A. Impact of land classification on potential warm season grass biomass production in Ontario, Canada. Can. J. Plant Sci. 2013, 93, 249-260. [CrossRef]

3. Ag Innovation Ontario, Ontario's Biomass Industry Ready to Grow by Seeking New Markets. Available online: https://www.aginnovationontario.ca/en/ontarios-biomass-industry-ready-to-grow-byseeking-new-markets/ (accessed on 5 September 2020).

4. Samson, R. Using Switchgrass and Miscanthus as a Sustainable Mulch; Ontario Biomass Producers Co-Operative Inc.: Markdale, ON, Canada, 2018; Available online: http://www.ontariobiomass.com/resources/Documents/ KTTProjects/KTTDocumentsandVideos/SwitchgrassandMiscanthusasaSustainableMulch.pdf (accessed on 5 September 2020).

5. Marsal, F.; Thevathasan, N.V.; Guillot, S.; Mann, J.; Gordon, A.M.; Thimmanagari, M.; Deen, W.; Silim, S.; Soolanayakanahally, R.; Sidders, D. Biomass yield assessment of five potential energy crops grown in southern Ontario, Canada. Agrofor. Syst. 2016, 90, 773-783. [CrossRef]

6. Deen, B. Biomass for Biofuel: Understanding the risks and opportunities for Ontario agriculture. Can. J. Plant Sci. 2017, 97, 964-971. [CrossRef]

7. Bazrgar, A.B.; Ng, A.; Coleman, B.; Ashiq, M.W.; Gordon, A.; Thevathasan, N. Long-Term Monitoring of Soil Carbon Sequestration in Woody and Herbaceous Bioenergy Crop Production Systems on Marginal Lands in Southern Ontario, Canada. Sustainability 2020, 12, 3901. [CrossRef]

8. McCalmont, J.P.; Hastings, A.; McNamara, N.P.; Richter, G.M.; Robson, P.; Donnison, I.S.; Clifton-Brown, J. Environmental costs and benefits of growing Miscanthus for bioenergy in the UK. GCB Bioenergy 2017, 9, 489-507. [CrossRef]

9. Lemus, R.; Lal, R. Bioenergy crops and carbon sequestration. Crit. Rev. Plant Sci. 2005, 24, 1-21. [CrossRef]

10. Felten, D.; Emmerling, C. Accumulation of Miscanthus-derived carbon in soils in relation to soil depth and duration of land use under commercial farming conditions. J. Plant Nutr. Soil Sci. 2012, 175, 661-670. [CrossRef]

11. Gelfand, I.; Sahajpal, R.; Zhang, X.; César Izaurralde, R.; Gross, K.L.; Robertson, G.P. Sustainable bioenergy production from marginal lands in the US Midwest. Nature 2013, 493, 514-517. [CrossRef] [PubMed]

12. Graham, J.; Voroney, P.; Coleman, B.; Deen, B.; Gordon, A.; Thimmanagari, M.; Thevathasan, N. Quantifying soil organic carbon stocks in herbaceous biomass crops grown in Ontario, Canada. Agrofor. Syst. 2019, 93, 1627-1635. [CrossRef]

13. Agostini, F.; Gregory, A.S.; Richter, G.M. Carbon Sequestration by Perennial Energy Crops: Is the Jury Still Out? Bioenergy Res. 2015, 8, 1057-1080. [CrossRef]

14. Volk, T.A.; Verwijst, T.; Tharakan, P.J.; Abrahamson, L.P.; White, E.H. Growing fuel: A sustainability assessment of willow biomass crops. Front. Ecol. Environ. 2004, 2, 411-418. [CrossRef]

15. Blanco-Canqui, H.; Lal, R. Crop Residue Management and Soil Carbon Dynamics; John Wiley \& Sons, Ltd.: Hoboken, NJ, USA, 2015; pp. 291-309.

16. Borak, B.; Ort, D.R.; Burbaum, J.J. Energy and carbon accounting to compare bioenergy crops. Curr. Opin. Biotechnol. 2013, 24, 369-375. [CrossRef] [PubMed]

17. Grant, B.B.; Smith, W.N.; Campbell, C.A.; Desjardins, R.L.; Lemke, R.L.; Kröbel, R.; McConkey, B.G.; Smith, E.G.; Lafond, G.P. Comparison of DayCent and DNDC Models: Case Studies Using Data from Long-Term Experiments on the Canadian Prairies; John Wiley \& Sons, Ltd.: Hoboken, NJ, USA, 2015; pp. 21-57. 
18. Jones, J.W.; Antle, J.M.; Basso, B.; Boote, K.J.; Conant, R.T.; Foster, I.; Godfray, H.C.J.; Herrero, M.; Howitt, R.E.; Janssen, S.; et al. Brief history of agricultural systems modeling. Agric. Syst. 2017, 155, 240-254. [CrossRef]

19. Necpálová, M.; Anex, R.P.; Fienen, M.N.; Del Grosso, S.J.; Castellano, M.J.; Sawyer, J.E.; Iqbal, J.; Pantoja, J.L.; Barker, D.W. Understanding the DayCent model: Calibration, sensitivity, and identifiability through inverse modeling. Environ. Model. Softw. 2015, 66, 110-130. [CrossRef]

20. Parton, W.J.; Hartman, M.; Ojima, D.; Schimel, D. DAYCENT and its land surface submodel: Description and testing. Glob. Planet. Chang. 1998, 19, 35-48. [CrossRef]

21. Del Grosso, S.; Parton, W.J.; Mosier, A.R.; Hartman, M.D.; Brenner, J.; Ojima, D.S.; Schimel, D.S. Simulated Interaction of Carbon Dynamics and Nitrogen Trace Gas Fluxes Using the DAYCENT Model. In Modeling Carbon and Nitrogen Dynamics for Soil Management; Schaffer, M.J., Ma, L., Hansen, S., Eds.; CRC Press: Boca Raton, FL, USA, 2002.

22. Bista, P.; Machado, S.; Ghimire, R.; Del Grosso, S.J.; Reyes-Fox, M. Simulating Soil Organic Carbon in a Wheat-Fallow System Using the Daycent Model. Agron. J. 2016, 108, 2554-2565. [CrossRef]

23. Davis, S.C.; Parton, W.J.; Dohleman, F.G.; Smith, C.M.; Del Grosso, S.; Kent, A.D.; DeLucia, E.H. Comparative biogeochemical cycles of bioenergy crops reveal nitrogen-fixation and low greenhouse gas emissions in a Miscanthus $\times$ giganteus agro-ecosystem. Ecosystems 2010, 13, 144-156. [CrossRef]

24. Robertson, A.D.; Zhang, Y.; Sherrod, L.A.; Rosenzweig, S.T.; Ma, L.; Ahuja, L.; Schipanski, M.E. Climate Change Impacts on Yields and Soil Carbon in Row Crop Dryland Agriculture. J. Environ. Qual. 2018, 47, 684-694. [CrossRef]

25. He, W.; Yang, J.Y.; Drury, C.F.; Smith, W.N.; Grant, B.B.; He, P.; Qian, B.; Zhou, W.; Hoogenboom, G. Estimating the impacts of climate change on crop yields and $\mathrm{N}_{2} \mathrm{O}$ emissions for conventional and no-tillage in Southwestern Ontario, Canada. Agric. Syst. 2018, 159, 187-198. [CrossRef]

26. Munroe, J.W.; McCormick, I.; Deen, W.; Dunfield, K.E. Effects of 30 Years of Crop Rotation and Tillage on Bacterial and Archaeal Ammonia Oxidizers. J. Environ. Qual. 2016, 45, 940-948. [CrossRef]

27. Soi1 Classification Working Group. The Canadian Sysfem of SoiI Classification; NRC Research press, Ottawa Publ. 1646 (Revised); Agriculture and Agri-Food Canada: Ottawa, ON, Canada, 1998; 187p.

28. IUSS Working Group WRB. World Reference Base for Soil Resources 2006; World Soil Resources Reports No. 103; FAO: Rome, Italy, 2007.

29. Kelly, R.H.; Parton, W.J.; Hartman, M.D.; Stretch, L.K.; Ojima, D.S.; Schimel, D.S. Intra-annual and interannual variability of ecosystem processes in shortgrass steppe. J. Geophys. Res. Atmos. 2000, 105, 20093-20100. [CrossRef]

30. Del Grosso, S.J.; Ojima, D.S.; Parton, W.J.; Stehfest, E.; Heistemann, M.; DeAngelo, B.; Rose, S. Global scale DAYCENT model analysis of greenhouse gas emissions and mitigation strategies for cropped soils. Glob. Planet. Chang. 2009, 67, 44-50. [CrossRef]

31. Del Grosso, S.J.; Mosier, A.R.; Parton, W.J.; Ojima, D.S. DAYCENT model analysis of past and contemporary soil $\mathrm{N}_{2} \mathrm{O}$ and net greenhouse gas flux for major crops in the USA. In Soil and Tillage Research; Elsevier: Amsterdam, The Netherlands, 2005; Volume 83, pp. 9-24.

32. Del Grosso, S.; Ojima, D.; Parton, W.; Mosier, A.; Peterson, G.; Schimel, D. Simulated effects of dryland cropping intensification on soil organic matter and greenhouse gas exchanges using the DAYCENT ecosystem model. Environ. Pollut. 2002, 116, S75-S83. [CrossRef]

33. Adler, P.R.; Del Grosso, S.J.; Parton, W.J. Life-cycle assessment of net greenhouse-gas flux for bioenergy cropping systems. Ecol. Appl. 2007, 17, 675-691. [CrossRef]

34. Environment and Climate Change Canada; Government of Canada. Available online: https://www.canada. ca/en/environment-climate-change.html (accessed on 15 September 2020).

35. Saxton, K.T.; Rawls, W. Soil Water Characteristics: Hydraulic Properties Calculator; Washington State University: Pullman, WA, USA, 2009. Available online: https://hrsl.ba.ars.usda.gov/soilwater/Index.htm (accessed on 9 September 2020).

36. Ramnarine, R.; Voroney, R.P.; Wagner-Riddle, C.; Dunfield, K.E. Conventional and No-Tillage Effects on the Distribution of Crop Residues and Light Fraction Organic Matter. Soil Sci. Soc. Am. J. 2015, 79, 74-80. [CrossRef]

37. Gaudin, A.C.M.; Tolhurst, T.N.; Ker, A.P.; Janovicek, K.; Tortora, C.; Martin, R.C.; Deen, W. Increasing Crop Diversity Mitigates Weather Variations and Improves Yield Stability. PLoS ONE 2015, 10, e0113261. [CrossRef] 
38. Hartman, M.D.; Parton, W.J.; Del Grosso, S.J.; Easter, M.; Hendryx, J.; Hilinski, T.; Kelly, R.; Keough, C.A.; Killian, K.; Lutz, S.; et al. DayCent Ecosystem Model. The Daily Century Ecosystem, Soil Organic Matter, Nutrient Cycling, Nitrogen Trace Gas, and Methane Model. User Manual, Scientific Basis, and Technical Documentation; Colorado State University: Fort Collins, CO, USA, 2017.

39. Jarecki, M.; Grant, B.; Smith, W.; Deen, B.; Drury, C.; VanderZaag, A.; Qian, B.; Yang, J.; Wagner-Riddle, C. Long-term Trends in Corn Yields and Soil Carbon under Diversified Crop Rotations. J. Environ. Qual. 2018, 47, 635-643. [CrossRef]

40. Wutzler, T.; Reichstein, M. Soils apart from equilibrium-consequences for soil carbon balance modelling. Biogeosciences 2007, 4, 125-136. [CrossRef]

41. Larson, B.M.; Riley, J.L.; Snell, E.A.; Godschalk, H.G. The Woodland Heritage of Southern Ontario: A Study of Ecological Change, Distribution and Significance; Federation of Ontario Naturalists: Toronto, ON, Canada, 1999; 262p.

42. Scinocca, J.F.; Kharin, V.V.; Jiao, Y.; Qian, M.W.; Lazare, M.; Solheim, L.; Flato, G.M.; Biner, S.; Desgagne, M.; Dugas, B. Coordinated global and regional climate modeling. J. Clim. 2016, 29, 17-35. [CrossRef]

43. Casler, M.D.; Vogel, K.P.; Taliaferro, C.M.; Ehlke, N.J.; Berdahl, J.D.; Brummer, E.C.; Kallenbach, R.L.; West, C.P.; Mitchell, R.B. Latitudinal and Longitudinal Adaptation of Switchgrass Populations; USDA-ARS/UNL Faculty: Washington, DC, USA, 2007. Available online: https:/digitalcommons.unl.edu/usdaarsfacpub/1938/ (accessed on 5 September 2020).

44. Linde-Laursen, I. Cytogenetic Analysis of Miscanthus Giganteus, an Interspecific Hybrid. Hereditas 2004, 119, 297-300. [CrossRef]

45. Heaton, E.; Voigt, T.; Long, S.P. A quantitative review comparing the yields of two candidate C4 perennial biomass crops in relation to nitrogen, temperature and water. Biomass Bioenergy 2004, 27, 21-30. [CrossRef]

46. Oliveira, J.A.; West, C.P.; Afif, E.; Palencia, P. Comparison of miscanthus and switchgrass cultivars for biomass yield, soil nutrients, and nutrient removal in northwest Spain. Agron. J. 2017, 109, 122-130. [CrossRef]

47. Eichelmann, E.; Wagner-Riddle, C.; Warland, J.; Deen, B.; Voroney, P. Carbon dioxide exchange dynamics over a mature switchgrass stand. GCB Bioenergy 2016, 8, 428-442. [CrossRef]

48. Samson, R.; Delaquis, E.; Deen, B.; Debruyn, J.; Eggimann, U. Switchgrass Agronomy; Ontario Biomass Producers Co-Operative Inc.: Markdale, ON, Canada, 2016.

49. Withers, K.; Deen, B.; Debruyn, J.; Eggimann, U. Miscanthus Agronomy; Ontario Biomass Producers Co-Operative Inc.: Markdale, ON, Canada, 2016.

50. Jamieson, P.D.; Porter, J.R.; Wilson, D.R. A test of the computer simulation model ARCWHEAT1 on wheat crops grown in New Zealand. Field Crop. Res. 1991, 27, 337-350. [CrossRef]

51. Garten, C.T. Review and model-based analysis of factors influencing soil carbon sequestration beneath switchgrass (Panicum virgatum). Bioenergy Res. 2012, 5, 124-138. [CrossRef]

52. Poeplau, C.; Don, A. Soil carbon changes under Miscanthus driven by $\mathrm{C} 4$ accumulation and C3 decomposition-toward a default sequestration function. GCB Bioenergy 2014, 6, 327-338. [CrossRef]

53. Haas, H.J.; Evans, C.E. Nitrogen and Carbon Changes in Great plains Soils as Influenced by Cropping and Soil Treatments; Technical Bulletins 157187; United States Department of Agriculture, Economic Research Service: Washington, DC, USA, 1957.

54. Dumanski, J.; Desjardins, R.L.; Tarnocai, C.; Monreal, C.; Gregorich, E.G.; Kirkwood, V.; Campbell, C.A. Possibilities for future carbon sequestration in Canadian agriculture in relation to land use changes. Clim. Chang. 1998, 40, 81-103. [CrossRef]

55. Barney, J.N.; DiTomaso, J.M. Bioclimatic predictions of habitat suitability for the biofuel switchgrass in North America under current and future climate scenarios. Biomass Bioenergy 2010, 34, 124-133. [CrossRef]

56. Hager, H.A.; Sinasac, S.E.; Gedalof, Z.; Newman, J.A. Predicting Potential Global Distributions of Two Miscanthus Grasses: Implications for Horticulture, Biofuel Production, and Biological Invasions. PLoS ONE 2014, 9, e100032. [CrossRef]

57. Nakajima, T.; Yamada, T.; Anzoua, K.G.; Kokubo, R.; Noborio, K. Carbon sequestration and yield performances of Miscanthus $\times$ giganteus and Miscanthus sinensis. Carbon Manag. 2018, 9, 415-423. [CrossRef] 
58. Del Grosso, S.J.; Parton, W.J.; Adler, P.R.; Davis, S.C.; Keough, C.; Marx, E. Daycent model simulations for estimating soil carbon dynamics and greenhouse gas fluxes from agricultural production systems. In Managing Agricultural Greenhouse Gases; Elsevier Inc.: Amsterdam, The Netherlands, 2012; pp. 241-250. ISBN 9780123868978.

Publisher's Note: MDPI stays neutral with regard to jurisdictional claims in published maps and institutional affiliations.

(C) 2020 by the authors. Licensee MDPI, Basel, Switzerland. This article is an open access article distributed under the terms and conditions of the Creative Commons Attribution (CC BY) license (http://creativecommons.org/licenses/by/4.0/). 